\title{
Toxicity determination of various phenoxyalkanoic acid herbicides using cress seed in phosphate contaminated aqueous media
}

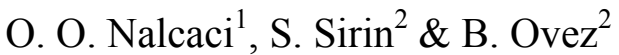 \\ ${ }^{I}$ Dokuz Eylül University, Mechanical Engineering Department, Turkey \\ ${ }^{2}$ Ege University, Chemical Engineering Department, Turkey
}

\begin{abstract}
In the industrial world there is growing evidence of ground water contamination. Environmentally relevant bio-tests provide information on initial levels of damage and disasters and assist in developing precautionary measures and strategies for the environment. Plant toxicity tests are not only quick and inexpensive relative to the more sophisticated chemical analyses, but also require less maintenance than other tests which use organisms.

In this research, garden cress seeds (Lepidium sativum $L$ ) were exposed to different phenoxyalkanoic acid herbicides 2,4-D(2,4-dicholorophenoxy) acetic acid), 2,4-DP((RS)-2,(2,4-dichlorophenoxy) propionic acid), 2,4-DB (4-(2,4dichlorophenoxy)butyric acid), 2,4,5-T (2,4,5-trichlorophenoxy)acetic acid), and MCPA (4-chloro-2-methylphenoxy) acetic acid) in a phosphate contaminated media for $120 \mathrm{~h}$ in order to determine the effect of toxicity to root growth. Each trial was duplicated for consistency of the experimental results (significance is taken as $\mathrm{p}<0.01$ ).

As an analytical approach IC50 (50\% inhibitory concentration) values of the substances were found from the graphical expressions of root length inhibitions. For the determination of the IC50 values, a non-linear regression model was applied using the least square method. The calculated IC50 values clearly represent the toxicity of the herbicides.

Keywords: aqueous media, garden cress seed (Lepidium sativum L.), herbicide toxicity, phosphate contamination, IC50.
\end{abstract}




\section{Introduction}

Water pollution is one of the most important environmental problems that humans must solve in the 21 st Century. To protect consumers from the adverse effects associated with high contamination intake, the United States, Canada, the $\mathrm{EU}$, and the WHO have set standards to regulate contamination concentrations in drinking water $[1,2]$. The subject of pesticide contamination in water has reached a particularly problematic level as a consequence of the European Commission directive on the Quality of Water Intended for Human Consumption (1980), which defines a Maximum Admissible Concentration of $0.1 \mu \mathrm{g} / \mathrm{L}$ for individual pesticides and of $0.5 \mu \mathrm{g} / \mathrm{L}$ for total of all pesticides present.

The widespread use of synthetic organic pesticides over the past half-century has led to their appearance in many hydrologic systems of the world [3-6].

Table 1: $\quad$ Solubility and $\mathrm{pK}_{\mathrm{a}}$ values of phenoxyalkanoic acid herbicides.

\begin{tabular}{|c|c|c|c|c|}
\hline Compound & Formula & $\begin{array}{l}\text { Solubility in } \\
\text { Water }(g / L)\end{array}$ & $\begin{array}{c}\text { Solubility in } \\
\text { organic solvent } \\
(\mathrm{g} / \mathrm{L})\end{array}$ & $\mathrm{pK}_{\mathrm{a}}$ \\
\hline MCPA & $\mathrm{C}_{9} \mathrm{H}_{9} \mathrm{ClO}_{3}$ & $\begin{array}{ll}0.55 & \left(20^{\circ} \mathrm{C}\right) \\
0.83 & \left(25^{\circ} \mathrm{C}\right) \\
1.17 & \left(25^{\circ} \mathrm{C}\right) \\
\end{array}$ & $\begin{array}{ll}\text { toluene } & 60 \\
\text { ether } & 770 \\
\text { ethanol } & 153 \\
\end{array}$ & $\begin{array}{l}2.90 \\
3.40\end{array}$ \\
\hline $2,4-\mathrm{D}$ & $\mathrm{C}_{8} \mathrm{H}_{6} \mathrm{Cl}_{2} \mathrm{O}_{3}$ & $\begin{array}{ll}0.50 & \left(20^{\circ} \mathrm{C}\right) \\
0.62 & \left(25^{\circ} \mathrm{C}\right) \\
0.73 & \left(25^{\circ} \mathrm{C}\right) \\
\end{array}$ & $\begin{array}{lc}\text { ether } & 270 \\
\text { acetone } & 850 \\
\text { ethanol } & 1300 \\
\end{array}$ & $\begin{array}{l}2.64 \\
2.80\end{array}$ \\
\hline 2,4-DP & $\mathrm{C}_{9} \mathrm{H}_{8} \mathrm{Cl}_{2} \mathrm{O}_{3}$ & $\begin{array}{ll}0.18 & (-) \\
0.35 & \left(20^{\circ} \mathrm{C}\right)\end{array}$ & $\begin{array}{lc}\text { toluene } & 70 \\
\text { acetone } & 600 \\
\text { isopropanol } 510\end{array}$ & $\begin{array}{l}3.00 \\
3.28\end{array}$ \\
\hline $2,4,5-\mathrm{T}$ & $\mathrm{C}_{8} \mathrm{H}_{5} \mathrm{Cl}_{3} \mathrm{O}_{3}$ & $\begin{array}{ll}0.24 & \left(20^{\circ} \mathrm{C}\right) \\
0.25 & \left(25^{\circ} \mathrm{C}\right) \\
0.27 & \left(25^{\circ} \mathrm{C}\right) \\
\end{array}$ & $\begin{array}{lc}\text { toluene } & 7 \\
\text { ether } & 230 \\
\text { ethanol } & 550 \\
\end{array}$ & $\begin{array}{l}3.14 \\
3.46\end{array}$ \\
\hline $2,4-\mathrm{DB}$ & $\mathrm{C}_{10} \mathrm{H}_{10} \mathrm{Cl}_{2} \mathrm{O}_{3}$ & $\begin{array}{l}0.05 \quad\left(25^{\circ} \mathrm{C}\right) \\
0.053 \quad(-)\end{array}$ & $\begin{array}{l}\text { ethanol soluble } \\
\text { acetone } 100\end{array}$ & $\begin{array}{l}4.58 \\
5.95\end{array}$ \\
\hline
\end{tabular}

Pesticides are very beneficial in agriculture, but when they have fulfilled their function, they may create environmental hazards. The phenoxyalkanoics mimic the action of plant growth hormones and act as systemic herbicides. Their chemical structure is a modification of naturally occurring plant hormonesauxins-causing uncontrolled growth of the meristematic tissues and restraining synthesis of DNA and proteins. Thus they disrupt basic metabolic processes in plant cell and tissues. They are widely used to control annual grasses and certain broadleaf weeds. Because of their toxicological properties, they are used in cereal crops. Grasses are resistant to phenoxyherbicides because of their ability to form durable conjunctions of phenoxyherbicides with cell structural compounds (mainly with glucose or other carbohydrates and amino acids). The 
metabolism and the environmental fate of phenoxyalkanoic acid herbicides have been extensively studied and reviewed. Some important properties of the compounds are given in the Table 1 [7].

The concentrations and toxicity in the terrestrial ecosystems for these compounds vary according to the formula used by the manufacturer and different environmental factors, for example; physical and chemical properties of soil, compound solubility in water, condition of organisms. 2,4-D and MCPA can be degraded in the soil by both abiotic and biological mechanisms. However, there is concern that these processes may not be sufficient to reduce the concentrations of chlorinated phenoxyacetic acids derivatives in soil $(0.6 \mathrm{mg} / \mathrm{kg}$ of dry matter $)$ and in surface water [8].

The effects of pesticides on soil microorganisms are studied for risk assessment because of the importance of microbes in soil processes. Toxicity of the MCPA in bacterial toxicity tests (EC50), the Pseudomonas putida $(62.5 \mathrm{mg} / \mathrm{L})$ and the luminescent bacteria test $(\mathrm{EC} 50=1.25 \mathrm{mg} / \mathrm{L})$ were detected in the clay soil [9].

The effects of 40 herbicides with nine modes of action on the green alga Raphidocells subcapitata were studied by 96-h acute toxicity tests. Results showed that the EC50 of the herbicides with respect to the photosynthetic processes of R. subcapitata ranged from 0.0007 to $4.2286 \mathrm{mg} / \mathrm{L}$. The EC50 of the MCPA was $13.7127 \mathrm{mg} / \mathrm{L}\left(4.56 \times 10^{-5} \mathrm{~mol} / \mathrm{L}\right)[10]$.

Fargasova [11] made seed germination and root growth inhibition tests using phenoxyherbicides. She found that the broad-leaved plant S. Alba roots are very sensitive to phenoxyherbicides. IC50 (72h) values for root were 1.17 and $1.58 \mathrm{mg} / \mathrm{L}$ for $2,4-\mathrm{D}$ and MCPA, respectively. These values were almost 100 times lower than those seed germination ones.

The present paper reports data concerning the ability of cress seeds (Lepidium sativum L.) to grow in media containing $\mathrm{KH}_{2} \mathrm{PO}_{4}$. The effect of different contaminations, phenoxyalkanoic acid herbicides (MCPA, 2,4-D, 2,4-DP, 2,4-DB and 2,4,5-T) on garden cress seed was investigated.

\section{Materials and methods}

Garden cress (Lepidium sativum L.) seeds were used and tested in $100 \mathrm{ml}$ of test solution. Test solutions were placed inside beakers with diameter $5.5 \mathrm{~cm}$, and height $7 \mathrm{~cm}$. Stainless steel filters were placed inside the beakers $3 \mathrm{~cm}$ from the top, submerged in the test concentration. Each test solution was investigated using at least 10 seeds.

The toxicity of herbicides $\left(2,4-\mathrm{D}\left(98 \%, \mathrm{FW}: 221.04, \mathrm{mp}: 136-140^{\circ} \mathrm{C}\right), 2,4-\mathrm{DP}\right.$ (95\%, FW:235.07, mp:110-112 $\left.{ }^{\circ} \mathrm{C}\right), 2,4-\mathrm{DB}$ (95\%, FW:249.1, mp:118-120 $\left.{ }^{\circ} \mathrm{C}\right)$ from Aldrich and MCPA (97\%, FW: 200.62, mp:114-118 $\left.{ }^{\circ} \mathrm{C}\right)$ Fluka Chemika techn., 2,4,5-T (97\%, FW:255. 49, mp:154-158 $\left.{ }^{\circ} \mathrm{C}\right)$ from Sigma Chemie $\mathrm{GmbH})$ were examined between the range of 0.001 and $10 \mathrm{ppm}$ in blank media (tap water) and $\mathrm{KH}_{2} \mathrm{PO}_{4}(10,20,40,80$ and $100 \mathrm{ppm})$ contaminated media. The tests were performed at room temperature (about $+20^{\circ} \mathrm{C}$ ), at natural light-dark regime, protected against direct sunlight. 
After $120 \mathrm{~h}$, root lengths were measured. Each trial is duplicated to ensure that root lengths are consistent within the two trials (significance is taken as $\mathrm{p}<$ $0.01)$.

Data Processing: For analyzing experimental data, mathematical models were created using nonlinear regression applying the least square method. Based on the values for the parameters describing the most suitable mathematical model, the values for IC50 (50\% inhibitory concentration) for garden cress root were determined.

\section{Results and discussion}

The aim of this research was to show the ability of cress seeds (Lepidium sativum L.) to grow in phosphate $\left(\mathrm{KH}_{2} \mathrm{PO}_{4}\right)$ contaminated water under the influence of different toxicants. Our previous studies with heavy metal toxicity $(\mathrm{Co}, \mathrm{Cr}, \mathrm{Cu}, \mathrm{Fe}, \mathrm{Mn}, \mathrm{Ni}, \mathrm{Pb})$ and our continuing research with pesticides (MCPA, 2,4-D, 2,4-DP, 2,4,5-T, 2,4-DB) will be discussed. The basis of our orders is the IC50 values (Table 2).

Table 2: $\quad$ IC50 (ppm) values for Lepidium sativum L. after exposure to different concentrations of the tested substances in blank media and different concentrations of $\mathrm{KH}_{2} \mathrm{PO}_{4}$ contamination.

\begin{tabular}{|c|ccc|ccc|ccc|}
\hline & \multicolumn{3}{|c|}{ Blank } & \multicolumn{3}{c|}{10 ppm } & \multicolumn{3}{c|}{ 20 ppm } \\
\hline 2,4- D & 0,0337 & \pm & $5,22 \mathrm{E}-04$ & 0,0264 & \pm & $1,68 \mathrm{E}-04$ & 0,0170 & \pm & $3,65 \mathrm{E}-04$ \\
\hline 2,4- DP & 0,0255 & \pm & $6,33 \mathrm{E}-04$ & 0,0360 & \pm & $5,89 \mathrm{E}-04$ & 0,0416 & \pm & $2,60 \mathrm{E}-04$ \\
\hline 2,4- DB & 1,3371 & \pm & $2,41 \mathrm{E}-02$ & 0,2445 & \pm & $3,06 \mathrm{E}-03$ & 0,2270 & \pm & $9,99 \mathrm{E}-04$ \\
\hline MCPA & 0,0246 & \pm & $1,40 \mathrm{E}-04$ & 0,0227 & \pm & $3,03 \mathrm{E}-04$ & 0,0216 & \pm & $3,26 \mathrm{E}-04$ \\
\hline 2,4, 5-T & 0,2859 & \pm & $1,04 \mathrm{E}-03$ & 0,3720 & \pm & $4,09 \mathrm{E}-04$ & 0,1043 & \pm & $5,79 \mathrm{E}-04$ \\
\hline & \multicolumn{4}{|c|}{$\mathbf{4 0} \mathbf{~ p p m}$} & \multicolumn{3}{c|}{$\mathbf{8 0} \mathbf{~ p p m}$} & \multicolumn{3}{c|}{$\mathbf{1 0 0} \mathbf{~ p p m}$} \\
\hline 2,4-D & 0,0271 & \pm & $8,83 \mathrm{E}-04$ & 0,0137 & \pm & $2,57 \mathrm{E}-04$ & 0,0122 & \pm & $3,63 \mathrm{E}-04$ \\
\hline 2,4-DP & 0,0389 & \pm & $5,16 \mathrm{E}-04$ & 0,0362 & \pm & $1,65 \mathrm{E}-04$ & 0,0210 & \pm & $3,09 \mathrm{E}-04$ \\
\hline 2,4- DB & 0,2046 & \pm & $3,67 \mathrm{E}-03$ & 0,1368 & \pm & $3,97 \mathrm{E}-03$ & 0,0436 & \pm & $1,22 \mathrm{E}-03$ \\
\hline MCPA & 0,0153 & \pm & $2,49 \mathrm{E}-04$ & 0,0119 & \pm & $2,34 \mathrm{E}-04$ & 0,0086 & \pm & $3,84 \mathrm{E}-04$ \\
\hline 2,4,5-T & 0,0686 & \pm & $7,68 \mathrm{E}-04$ & 0,0654 & \pm & $2,88 \mathrm{E}-03$ & 0,0266 & \pm & $4,66 \mathrm{E}-04$ \\
\hline
\end{tabular}

The toxicity of different metal ions $(\mathrm{Co}, \mathrm{Cr}, \mathrm{Cu}, \mathrm{Fe}, \mathrm{Mn}, \mathrm{Ni}, \mathrm{Pb})$ using cress (Lepidium sativum L) seeds were investigated. In the first part of experiments the cress seeds were subjected to an aqueous media without the phosphate $\left(\mathrm{KH}_{2} \mathrm{PO}_{4}\right)$ contamination. In this blank media the toxicity order of the investigated metal ions from least toxic to most toxic was; $\mathrm{Pb}<\mathrm{Co}<\mathrm{Fe}<\mathrm{Mn}<\mathrm{Cr}<\mathrm{Cu}<\mathrm{Ni}$. The experimental study was furthered by exposing the cress seeds to $10 \mathrm{ppm}$ and $40 \mathrm{ppm}$ phosphate $\left(\mathrm{KH}_{2} \mathrm{PO}_{4}\right)$ contamination. The result was a change in the toxicity order of the ions. The order, from least toxic to most toxic became $\mathrm{Pb}<\mathrm{Mn}<\mathrm{Cu}<\mathrm{Co}<\mathrm{Fe}<\mathrm{Ni}<\mathrm{Cr}, \mathrm{Pb}<\mathrm{Mn}<\mathrm{Cu}<\mathrm{Co}$, under 10 ppm and 40 ppm phosphate $\left(\mathrm{KH}_{2} \mathrm{PO}_{4}\right)$ contamination respectively. The lack of three ions under 40 ppm phosphate $\left(\mathrm{KH}_{2} \mathrm{PO}_{4}\right)$ contaminations is due to the high levels of toxicity which prohibited us from calculating IC50 values of the ions. As can be 
seen, the addition of phosphate $\left(\mathrm{KH}_{2} \mathrm{PO}_{4}\right)$ has a different impact for each metal ion. The interaction of phosphate and the metal ions created different contamination levels. This phenomenon was investigated [12].

We have continued our research with phenoxyalkanoic acid herbicides, instead of heavy metal ions. Again in the first part of our experiments the five investigated herbicides were subjected to a non-phosphate contaminated media. The toxicity order of the herbicides were 2,4-DB $<2,4,5-\mathrm{T}<2,4$-DP $<2,4-\mathrm{D}<$ MCPA. This result is in correlation with Fargasova, 1994, who used the broadleaved plant S. Alba roots, has found 2,4-D less toxic than MCPA. GrabińskaSota et al [13] researched the responses of different test plants, Sinapis alba, Avena sativa, Triticum aestivum to herbicides. According to his results 2,4-D is the less lethal than MCPA. Also according to the same study cress (L. sativum) seeds provide the most sensitive results.

To continue our study we have subjected the cress seeds to various levels (10, $20,40,80,100 \mathrm{ppm})$ of phosphate $\left(\mathrm{KH}_{2} \mathrm{PO}_{4}\right)$ contamination. The resulting orders were as follows

$\begin{array}{ll}10 \mathrm{ppm} & 2,4,5-\mathrm{T}<2,4-\mathrm{DB}<2,4-\mathrm{DP}<2,4-\mathrm{D}<\text { MCPA } \\ 20 \mathrm{ppm} & 2,4-\mathrm{DB}<2,4,5-\mathrm{T}<2,4-\mathrm{DP}<\text { MCPA }<2,4-\mathrm{D} \\ 40 \mathrm{ppm} & 2,4-\mathrm{DB}<2,4,5-\mathrm{T}<2,4-\mathrm{DP}<2,4-\mathrm{D}<\text { MCPA } \\ 80 \mathrm{ppm} & 2,4-\mathrm{DB}<2,4,5-\mathrm{T}<2,4-\mathrm{DP}<2,4-\mathrm{D}<\text { MCPA } \\ 100 \mathrm{ppm} & 2,4-\mathrm{DB}<2,4,5-\mathrm{T}<2,4-\mathrm{DP}<2,4-\mathrm{D}<\text { MCPA }\end{array}$

These results show that with or without phosphate contamination, the toxicity of the investigated phenoxyalkanoic acid herbicides does not change dramatically. This indicates the interaction between the phosphate and metal ions is not a significant factor between phosphate and the herbicides. According to Akcay and Yurdokoç [7] the adsorption of the phenoxyalkanoic acid herbicides on organoclays decreased in the order of 2,4-DB $>2,4,5-\mathrm{T}>2,4-\mathrm{DP}>2,4-\mathrm{D}>$ MCPA. Comparison of the two different experiment results, according to our results this will indicate that the toxicity of the phenoxyalkanoic acid herbicides is very much dependant on their adsorption properties.

\section{Conclusion}

The aim of this research was to show the ability of cress seeds (Lepidium sativum L.) to grow in phosphate $\left(\mathrm{KH}_{2} \mathrm{PO}_{4}\right)$ contaminated water under the influence of different toxicants (MCPA, 2,4-D, 2,4-DP, 2,4,5-T, 2,4-DB).

Our results shows that based on the IC50 values of blank solutions, the toxicity order of phenoxy alkanoic acid herbicides are 2-4 DB $<2-45<2-4$ DP $<2-4 \mathrm{D}<$ MCPA. Under different levels of phosphate $\left(\mathrm{KH}_{2} \mathrm{PO}_{4}\right)$ contamination this order show little or no change, which leads to the conclusion that pesticides and phosphate interaction does not play a significant role in their final toxic behaviours.

It is apparent that cress seeds (Lepidium sativum L.) are quite sensitive in phenoxyalkanoic acid herbicides contamination analysis. The seeds are easily 
affected by different contaminations and contamination levels, which make them ideal for research purposes.

\section{Acknowledgement}

The project was supported by TUBITAK (The Scientific and Technological Research Council of Turkey)

\section{References}

[1] Sayre, I.M., International Standards for drinking water, American Water Works Association, 80, 53, 1988.

[2] Deininger, R.A., Literathy, P., Bartram, J., Security of Public Water Supplies, Nato Science Series, 2. Environmental, 66, 1998.

[3] Albanis, T.A., Danis, T.G., Hela, G.D., Transportation of pesticides in Estuaries of Louros and Arachthos rivers, Science of the Total Environment, 171, 85-93, 1995.

[4] Kolpin, W.K., Barbash, J.E., Gilliom, R.J., Occurrence of pesticides in shallow groundwater of the United States, Environ. Sci. Technol., 32, 558566, 1998.

[5] Schuette, S.A., Smith, R.G., Holden, L.R., Graham, J.A., Solid Phase extraction of herbicides from well water for determination by gas chromatography-mass spectrometry, Analytica Chimica Acta, 236, 141144, 1990.

[6] Biziuk, M., Przyjazny, A., Czerwiski, J., Wiergowski, M., Occurrence and determination of pesticides in natural and treated waters, Journal of Chromatography A, 754, 103-123, 1996.

[7] Akçay, G., Yurdakoç, K., Removal of various phenoxyalkanoic acid herbicides from water by organo-clays. Acta Hydrochim. Hydrobiol. 28, 300-304, 2000.

[8] Kamrin, M.A., Pesticide profiles toxicity, environmental impact and fate, Levis Publishers, New York, 1997.

[9] Ahtiainen, J.H., Vanhala, P., Myllymäki, A., Effects of different plant protection programs on soil microbes, Ecotoxicology and Environmental Safety, 54, 56-64, 2003.

[10] Ma, J., Wang, S., Wang, P., Ma, L., Chen, X., Xu, R., Toxicity assessment of 40 herbicides to the green alga Raphidocelis subcapitata, Ecotoxicology and Environmental Safety, 63, 456-462, 2006.

[11] Fargasova, A., Comparative study of plant growth hormone (herbicide) toxicity in various biological subjects, Ecotoxicology and Environmental Safety, 29, 359-364, 1994.

[12] Ozgen, S., Nalcaci , O.O., Ovez , B., Metal Toxicity Determination Using Cress Seed In Phosphate Contaminated Media, EMCC-4 Proceedings, The $4^{\text {th }}$ Eastern Mediterranean Chemical Engineering Conference for Collaborative Research in Mediterranean Countries, 373-376, 2006. 
[13] Grabińska-Sota, E., Wiśniowska, E., Kalka, J., Toxicity of Selected Synthetic Auxines 2,4-D and MCPA derivatives to broad-leaved and cereal plants, Crop Protection, 22, 355-360, 2003 